\title{
PELATIHAN PEMBUATAN ALAT FILTER IPAL KOMUNAL DENGAN PEMANFAATAN LIMBAH BOTOL PLASTIK
}

\author{
${ }^{1}$ Nopia Wati, ${ }^{2}$ Hasan Husin, ${ }^{3}$ Andri Kusuma Wijaya, ${ }^{4}$ Agus Ramon \\ ${ }^{1,2,4)}$ Program Studi Kesehatan Masayrakat, Fakultas Ilmu Kesehatan, \\ Universitas Muhammadiyah Bengkulu \\ 3) Program Studi Keperawatan, Fakultas Ilmu Kesehatan, \\ Universitas Muhammadiyah Bengkulu \\ Corresponding author : nopia@umb.ac.id
}

Informasi Artikel

Terima : 31/03/2021

Revisi : 22/05/2021

Disetujui : $12 / 08 / 2021$

Kata Kunci:

Pelatihan, Filter

IPAL, Botol Plastik

\begin{abstract}
ABSTRAK
Perancangan ini di latar belakangi oleh limbah botol plastik yang semakin menumpuk. Limbah botol plastik masih dianggap kurang bermanfaat. Padahal limbah botol plastik dapat dimanfaatkan menjadi beraneka ragam bentuk. Dalam proses daur ulang limbah botol plastik diperlukan beberapa proses agar daur ulang limbah botol plastik dapat dimanfaatkan. Sebelum didaur ulang perlu adanya proses pencucian agar kotoran padat maupun kimia yang terkandung pada limbah botol plastik dapat diminimalisir. Permasalahan mitra yaitu masyarakatnya memiliki ekonomi rendah dan sebagian warganya bekerja di tempat pembuangan akhir sampah di Air Sebakul, untuk memenuhi kebutuhan vital mereka sehari-hari menjadi pemulung sampah. Walaupun pekerjaan mereka bergelut dibidang persampahan, tetapi mereka tidak memahami bagaimana cara mengelolah sampah tersebut supaya dapat dijadikan sebagai penambah perekonomian keluarganya. Masyarakat sekitar juga.banyak yang belum mengetahui dampak yang ditimbulkan jika limbah botol plastic ini tidak dikelolah dengan baik. Masyarakat juga belum belum mengetahui bagaimana cara pemanfaatan limbah botol plastic ini sebagai filter untuk IPAL. Pada kegaiatan ini masyarakat diberikan sosialisasi dan pelatihan tentang pembuatan filter IPAL dengan memanfaatkan limbah botol plastik yang mudh didapatkan oleh masyarakat sekitar. Setelah dilakukan kegiatan pengabdian ini dapat menambah pengetahuan dan kemampuan masyarakat dalam mengelolah sampah plastic botol bekas, dan dapat dijadikan sebagai peluang usaha untuk menambah perekonomian keluarga.
\end{abstract}

PENDAHULUAN

Sampah plastik sudah menjadi permaslahan serius di Indonesia, terutama di daerah perkotaan.

Kebanyakan masyarakat memilih untuk membuang sampah plastik diberbagai 
tempat umum seperti di jalan, sungai atau perkarangan kosong. Mengingat sampah plastik sulit terurai maka akan menganggu kebersihan dan kesehatan lingkungan. Apabila pembuangan sampah semakin tidak terkendali akan berakibat menumpuknya sampah di Tempat Penampungan Sementara (TPS) dan Tempat Pembuangan Akhir (TPA). Salah satu jenis sampah yang cukup banyak adalah sampah botol plastik. Komposisi sampah plastik di Indonesia saat ini sekitar $15 \%$ dari total timbulan sampah, terutama di daerah perkotaan. Timbulan sampah plastik yaitu 10-15\% didaur ulang, 60-70 persen ditampung di tempat pembuangan akhir (TPA), 15 $30 \%$ belum terkelola dan $15-30$ persen sampah plastik yang belum terkelola terbuang ke lingkungan, terutama ke sungai, danau, pantai, dan laut.

Menurut Ditjen Cipta Karya Departemen Pekerjaan Umum (2007), sampah merupakan suatu buangan atau produk sisa dalam bentuk padat sebagai kegiatan manusia yang dianggap sudah tidak bermanfaat lagi. Menurut Yuwono dan Abdullah (1994:262) limbah adalah bahan sisa yang dihasilkan dari suatu kegiatan dan proses produksi, baik pada skala rumah tangga, industri, pertambangandan sebagainya.
Penggunaan plastik dalam kehidupan manusia semakin lama semakin meningkat. Peningkatan pemanfaatan plastik ini terjadi karena plastik bersifat ringan, plastik ekonomi dan dapat menggatikan fungsi dari barang-barang lain. Sifat praktis ekonomi ini menyebabkan plastik sering dijadikan barang sekali pakai, sehingga semakin banyaknya penggunaan perlengkapan dari bahan plastik terutama dalam kemasan air minum yang terbuat dari botol plastik.Limbah botol plastik masih dianggap kurang bermanfaat. Padahal limbah botol plastik dapat dimanfaatkan menjadi beraneka ragam bentuk barang yang berguna melalui proses daur ulang. Menurut Nasiri (2004) secara umum plastik mempunyai sifat yaitu densitas yang rendah; isolasi terhadap listrik; mempunyai kekuatan mekanik yang bervariasi; ketahanan terhadap suhu terbatas; ketahanan terhadap bahan kimia bervariasi. Dalam proses daur ulang sampah botol plastik diperlukan beberapa proses agar daur ulang limbah botol plastik tersebut bisa dimanfaatkan.

Seperti halnya dengan Filter botol plastik ini dimanfaatkan sebagai media untuk mengembangkan bakteri 
pengurai limbah didalam tanki septik tank.

Sistem kerjanya Filter IPAL ini adalah air limbah akan masuk tersaring mengalir melalui botol-botol sebagai menampung lumpur-lumpurnya, sehingga air kemudian bisa dibuang dalam kondisi bersih, dan tidak menimbulkan penyakit serta tidak mencemari lingkungan

Demi mengurangi dampak negatif dari sampah botol plastik bekas berbagai jenis teknologi pemanfaatan botol plastik dikembangkan, diantaranya adalah penggunaan botol plastik sebagai media biofilter Dalam pembuatan satu sistem IPAL tersebut dibutuhkan sekitar 8 ribu botol kemasan air mineral ukuran 1,5 liter. Botol-botol tersebut nantinya disusun sedemikan rupa tanpa ada unsur atau bahan lainnya. Ukuran IPAL sepanjang 7,5 meter dengan lebar 1,5 meter dan berkedalaman 2,5 meter. Kapasitas IPAL dapat mencapai sebanyak 50 kepala keluarga.

Daerah Karang Indah RT 08 RW 03 adalah salah satu daerah yang terdapat di Kota Bengkulu, dimana masyarakatnya memiliki ekonomi rendah dan sebagian warganya bekerja di tempat pembuangan akhir sampah di Air Sebakul, untuk memenuhi kebutuhan vital mereka sehari-hari menjadi pemulung sampah. Walaupun pekerjaan mereka bergelut dibidang persampahan, tetapi mereka tidak memahami bagaimana cara mengelolah sampah tersebut supaya dapat dijadikan sebagai penambah perekonomian keluarganya. Masyarakat sekitar juga.banyak yang belum mengetahui dampak yang ditimbulkan jika limbah botol plastic ini tidak dikelolah dengan baik. Masyarakat juga belum belum mengetahui bagaimana cara pemanfaatan limbah botol plastic ini sebagai filter untuk IPAL .

Berdasarkan permasalahan mitra yang diuraikan di atas, solusi yang dapat dilakukan adalah dengan cara memberikan pelatihan kepada masyarakat di Daerah Karang Indah RT 08 RW 03 untuk melakukan pengelolaan sampah anorganik yang membahayakan kesehatan ini dengan memanfaatkan kembali limbah botol plastik untuk digunakan sebagai filter IPAL komunal. Dengan harapan dapat menambah kemampuan dan pengetahuan masyarakat sekitar lokasi dan hasil ini dapat diterapkan sebagai ladang ilmu mereka guna meningkatkan perekonomian keluarga. 


\section{METODE PELAKSANAAN}

Arah Pemberdayaan Masyarakat Bidang Kesehatan Mengacu pada tujuan pembangunan jangka panjang bidang kesehatan yaitu : 1) peningkatan kemampuan masyarakat untuk menolong dirinya sendiri dalam bidang kesehatan; 2) perbaikan mutu lingkungan hidup yang dapat menjamin kesehatan; 3) peningkatan status gizi masyarakat; 4) pengurangan kesakitan (morbiditas) dan kematian (mortalitas), $\begin{array}{lll}\text { serta } & 5 \text { ) pengembangan keluarga }\end{array}$ berkualitas. Dalam rangka mencapai tujuan tersebut dilaksanakan upaya antara lain : 1) pengembangan peningkatan swadaya masyarakat dalam pembangunan kesehatan dengan pendekatan edukatif dan 2) pembinaan peran serta masyarakat termasuk swasta dalam upaya kesehatan.

Berdasarkan upaya tersebut maka pelaksanaan dan pembinaan pemberdayaan masyarakat bidang kesehatan diarahkan pada 1) pemberdayaan aparat bertujuan agar aparat lebih mampu, responsif dan akomodatif, dan 2) pemberdayaan rakyat bertujuan agar rakyat lebih mampu, proaktif dan aspiratif. Dengan demikian pemberdayaan masyarakat bidang kesehatan merupakan suatu proses membangun manusia atau masyarakat melalui pengembangan kemampuan masyarakat, perubahan perilaku dan pengorganisasian masyarakat bidang kesehatan. Oleh karena itu, pelaksanaan dan pembinaan pemberdayaan masyarakat bidang kesehatan, secara umum ditujukan pada meningkatnya kemandirian masyarakat dan keluarga dalam bidang kesehatan sehingga masyarakat dapat memberikan andil dalam meningkatkan derajat kesehatannya. Secara khusus ditujukan pada : meningkatnya pengetahuan masyarakat dalam bidang kesehatan; meningkatnya kemampuan masyarakat dalam pemeliharaan dan peningkatan derajat kesehatannya sendiri; meningkatnya pemanfaatan fasilitas pelayanan kesehatan oleh masyarakat; dan terwujudnya pelembagaan upaya kesehatan bersumber daya masyarakat.

$$
\text { Strategi pemberdayaan }
$$
masyarakat bidang kesehatan mencakup adalah pemberdayaan masyarakat merupakan suatu upaya dalam peningkatan kemampuan masyarakat guna meningkatkan harkat hidup, martabat dan derajat kesehatannya; Peningkatan keberdayaan berarti peningkatan kemampuan dan kemandirian masyarakat agar dapat 
mengembangkan diri dan memperkuat sumber daya yang dimiliki untuk mencapai kemajuan.

a. Persiapan Kegiatan (Minggu Ke 1)

Pada Minggu pertama Tim menyusun rencana kegiatan mulai dari persiapan sampai rencana perbaikan dan melakukan sosialisasi dan koordinasi dengan perangkat desa, karang taruna dan tokoh masyarakat

b. Pelaksanaan

(Minggu ke 2 s.d ke 3)

Sosialisasi ke kepada masyarakat tentang pengelolaan sampah dengan baik dan dampak yang ditimbulkan dari sampah plastik jika tidak dikelolah, melakukan pelatihan kepada masyarakat tentang cara pembuatan filter IPAL Komunal dengan pemanfaatan Limbah Botol Plastik dan menghimbau kepada masyarakat supaya dapat memnfaatkan hasil kegiatan ini sebagai usaha untuk menambah perekonomian.

\section{HASIL DAN PEMBAHASAN}

a. Kegiatan Survei Lapangan

Kegiatan survei lapangan dilaksanakan oleh tim yang bertujuan untuk menganalisis lokasi atau situasi dan sasaran peserta. Selain itu jug kegiatan survey lapangan dimaksudkan untuk mengidentifikasi kondisi terkini mitra. Dalam kegiatan ini juga dibicarakan terkait tema atau materi penyuluhan kesehatan yang akan diberikan oleh tim pengabdian kepada masyarakat kepada mitra, khususnya masyarakat di Daerah Karang Indah RT 08 RW 03 Kel. Sumur Dewa Kec. Selebar Kota Bengkulu.

\section{b. Kegiatan Pengabdian}

1) Pembukaan Acara dimulai dengan pembukaan dari ketua RT 08 yaitu Bapak Bahari yang dihadiri oleh tim pengabdian pada masyarakat (pengmas) FIKES UM Bengkulu, dan Masyarakat di Daerah Karang Indah. 


\section{2) Pelaksanaan}
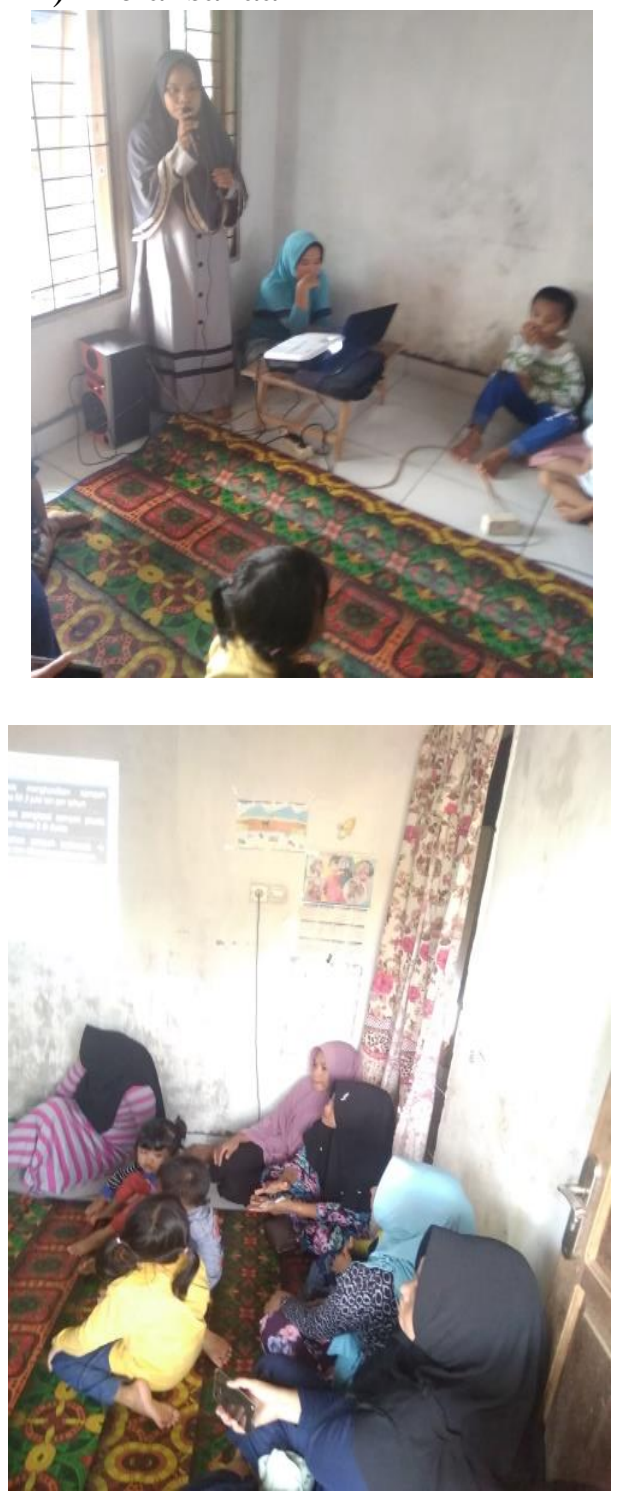

(Gambar 1. Pelaksanaan penyuluahan)

Pelaksanaan kegiatan diawali dengan membuat MoU (Memorandum of Understanding) antara Tim Pengabdian pada Masyarakat Fakultas Ilmu Kesehatan Universitas Muhammadiyah Bengkulu, yang dalam hal ini diwakili oleh Ketua Tim dengan Ketua RT 08 RW 03 Kel. Sumur Dewa Kec. Selebar Kota Bengkulu,. Selain itu, dalam tahap awal ini juga dilakukan penandatanganan pernyataan kesediaan pihak RT 08 sebagai mitra dalam pelaksanaan kegiatan pengabdian kepada masyarakat Program Kemitraan Masyarakat Stimulus (PKMS), yang dalam hal ini diwakili juga oleh Ketua RT 08

Tahap selanjutnya melakukan kegiatan survei lapangan dan penentuan tema atau materi penyuluhan kesehatan yang akan diberikan berdasarkan hasil survei lapangan yang telah dilakukan.

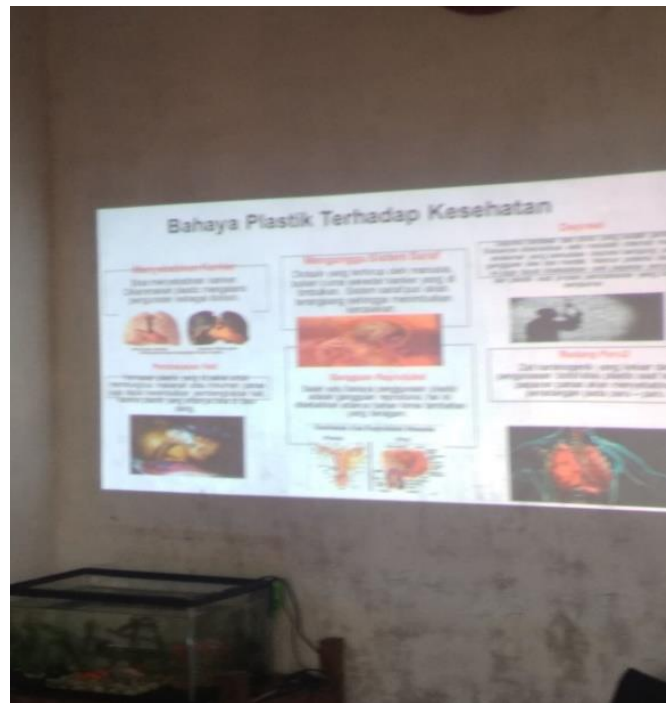

Gambar 2. Penyampaian Materi Penyakit Yang Muncul Akibat Sampah Sampah Plastik

Pelaksanaan penyuluhan kesehatan yang pertama tentang dampak sampah plastik terhadap kesehatan, yang dilakukan oleh tim pengmas dengan lokasi adalah di lingkungan RT 08 . Setelah materi disampaikan, tim memberikan kesempatan kepada warga 
untuk bertanya seputar materi yang telah disampaikan ataupun pertanyaan seputar tentang dampak sampah plastik. Diakhir penyuluhan memberikan tayangan video tentang dampak sampah plastik terhadap kesehatan, dengan harapan dapat memahamai dan tidak melakukan pembuangan dan pembakaran sampah sembarangan di lingkungan sekitar rumah.
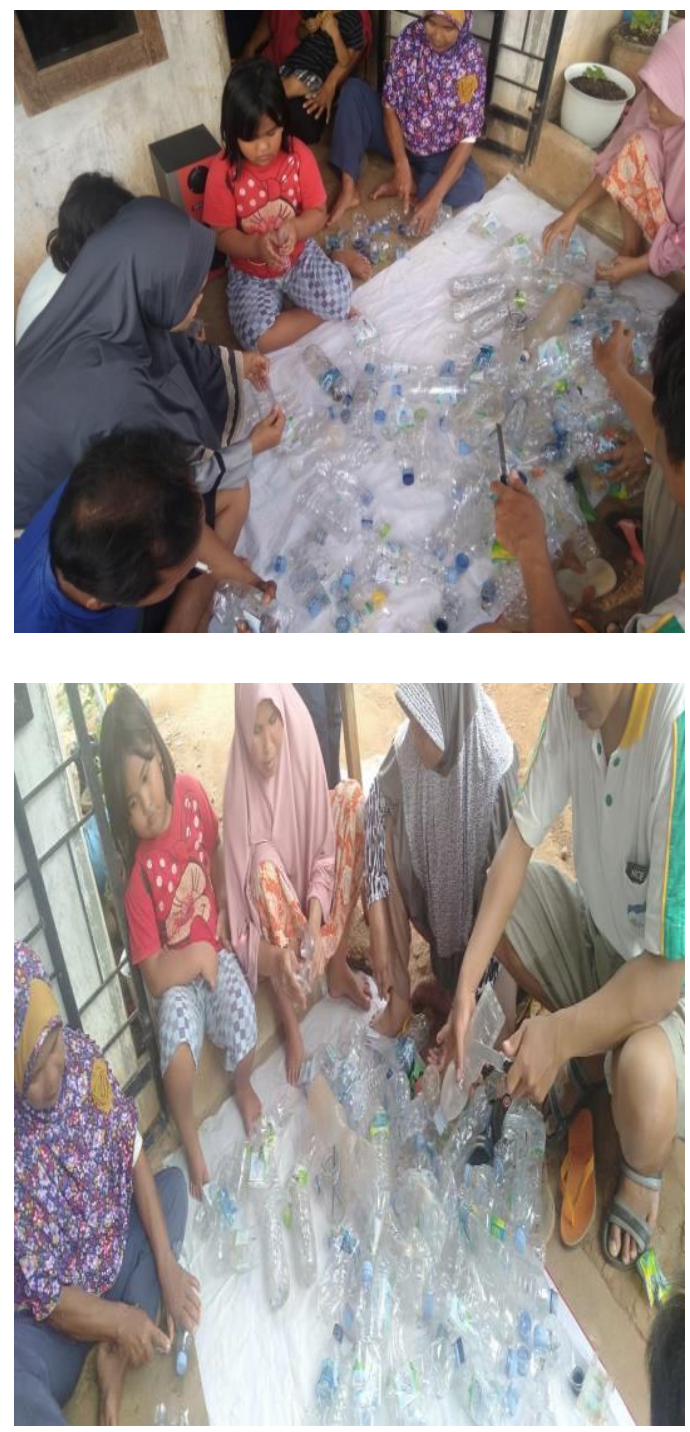

Gambar 3. Pelatihan Pembuatan

Filter IPAL Komunal

Penyuluhan kedua tim pengmas memberikan penyuluhan tentang pemanfaatan botol plastik sebagai filter IPAL dan menambah nilai ekonomi keluarga, Selanjutnya tim pengmas memberikan pelatihan pembuatan filter IPAL Komunal kepada warga di Daerah Karang Indah RT 08. Di akhir penyuluhan, tim pengmas beserta warga melakukan demontrasi pembuatan filter IPAL dari botol plastik, dengan harapan warga dapat memiliki kemampuan dalam mendaur ulang sampah botol plastik menjadi nilai tambah ekonomi keluarga.

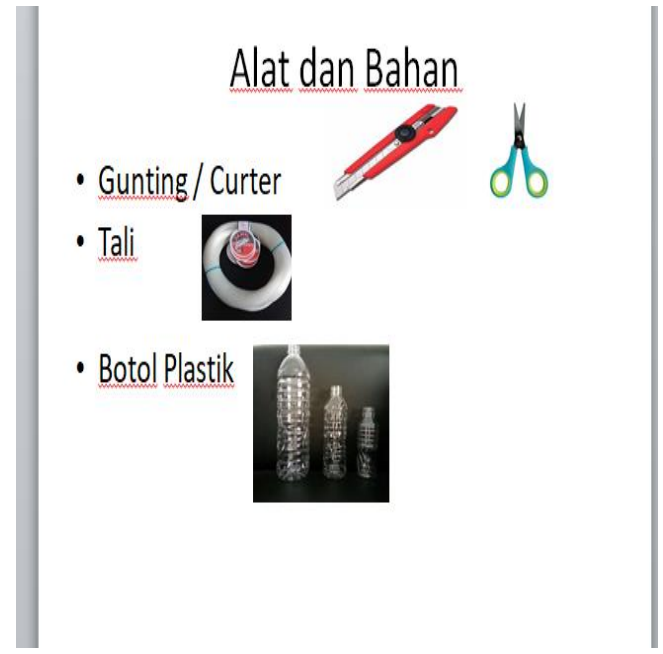

Cara Pembuatan

a. Botol plastik di potong bagian atas dan bawahnya,

b. botol yang sudah dipotong sebagian untuk wadah filter 
berbentuk silinder dan sebagian dilipat sebagai filter.

c. Kemudian dilipat dan dimasukkan kedalam botol bentuk silinder dengan beberapa lapisan.

d. Lalu botol-botol yang sudah dibentuk dirangkai dan diikat untuk menjadi filter.

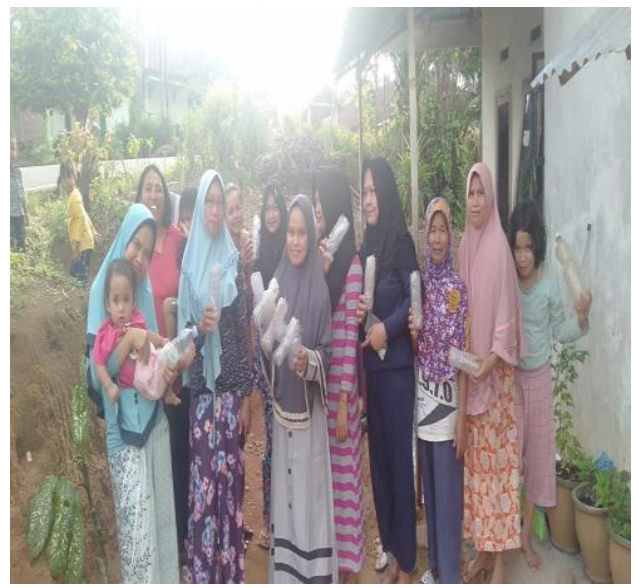

Gambar 4. Dokumentasi dengan warga

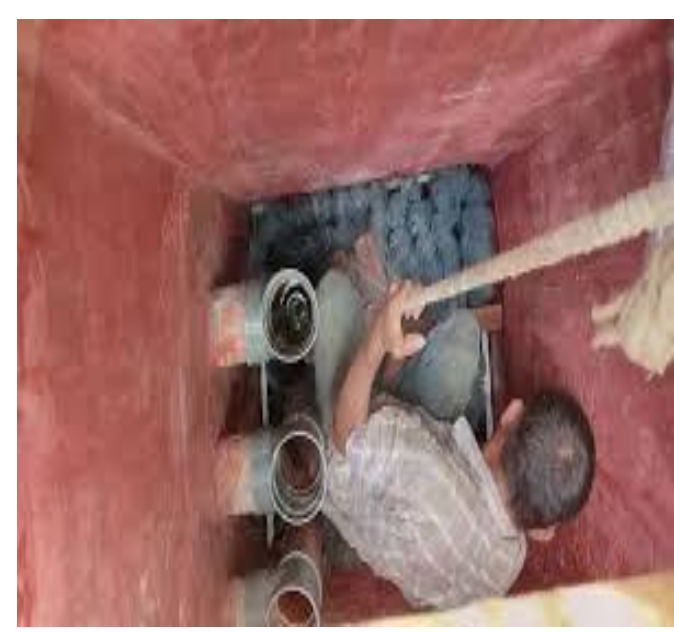

Gambar 5. Cara pemasangan Filter IPAL

Selanjutnya tim menyelesaikan dokumentasi, administrasi surat-surat dan laporan kegiatan hasil pengabdian kepada masyarakat di RT 08 RW 03
Kel. Sumur Dewa Kec. Selebar Kota Bengkulu.

3) Evaluasi

Untuk penyuluhan kesehatan tentang dampak sampah plastic terhadap kesehatan di minggu pertama, respon dari warga sangat baik. Sebagian besar warga memiliki antusias menanyakan hal-hal terkait tentang dampak sampah plastik. Setelah mengetahui dampak sampah plastic ini terhadap kesehatan, masyarakat memiliki tekad untuk tidak membuang dan membakar sampah plastik sembarangan di lingkungan sekitar. Materi tentang dampak limbah plastic terhadap kesehatan yang diberikan meningkatkan pengetahuan dan merubah perilaku warga terkait dampak sampah plastik jika dibuang dan dibakar sembarang terhadap diri mereka dan keluarganya,

Manfaat yang didapatkan dari hasil kegiatan pengabdian ini adalah Selain dapat membantu mengurangi sampah plastik, menambah wawasan dan pengetahuan warga tentang daur ulang sampah dengan cara pembuatan filter IPAL dan juga dapat membantu masyarakat secara nilai ekonomis. Dimana setiap produksi filter satu kubik , harga antara Rp. 1,5 - Rp. 1,6 juta. 
Warga bisa menjualnya ke pelaksana sekitar Rp. 1,9 juta. Dengan begitu untungnya bisa sampai Rp. 400 ribu. Kalikan lima saja, bisa sampai Rp. 2 juta.
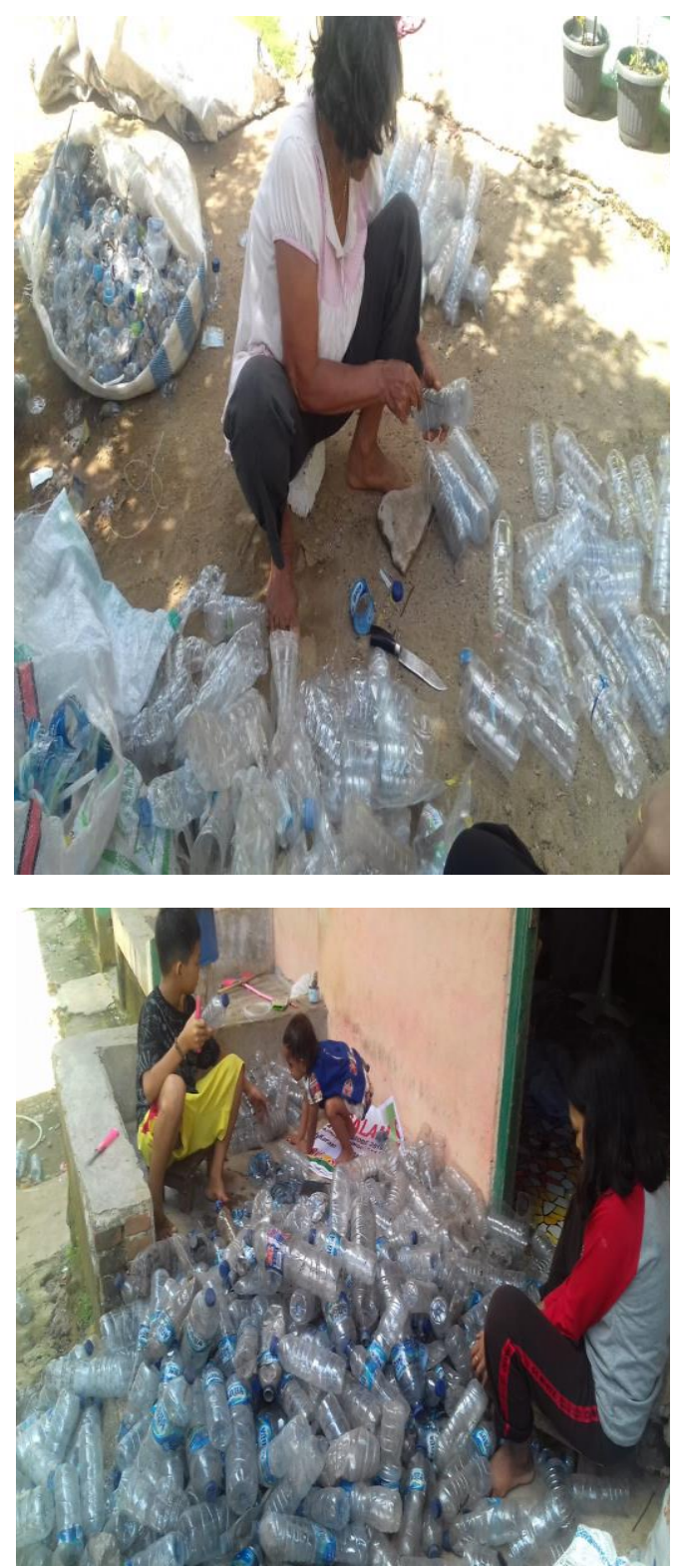

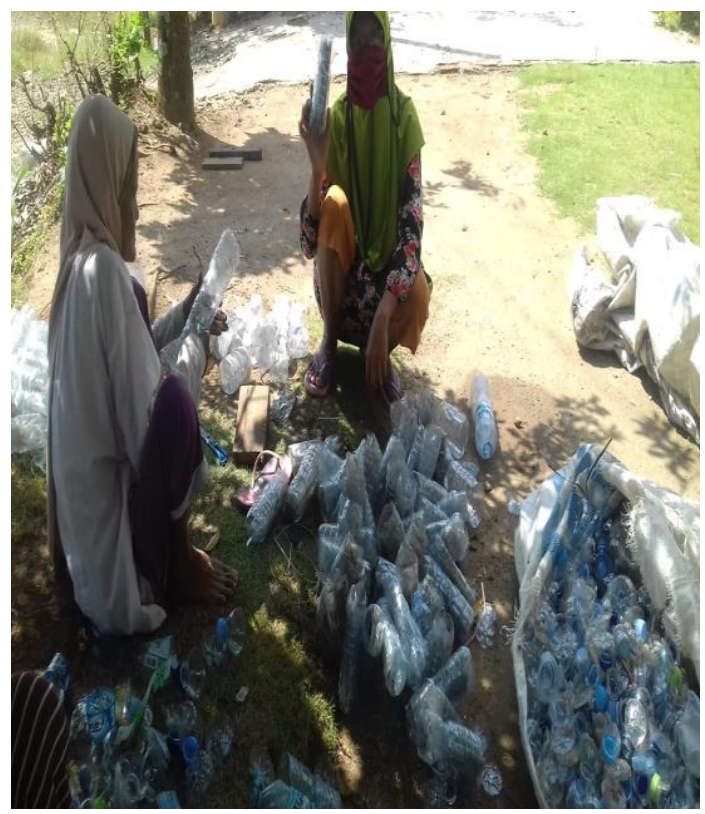

Gambar 6. Warga secara mandiri membuat filter IPAL

Sementara untuk penyuluhan kesehatan tentang pemanfaatan botol plastik bekas sebagai filter IPAL Komunal sebagai nilai tambah ekonomi yang dilaksanakan di minggu berikutnya, juga mendapat respon antusias dari warga. Banyak warga yang bertanya terkait daur ulang sampah botol plastik, cara pembuatan filter IPAL yang benar, sistem pemasangannya di IPAL dan keberlanjutan kerjasama pada pihak proyek pembuatan IPAL Komunal. Dengan diberikannya materi ini warga dapat mengetahui bagaimana daur ulang sampah plastic seperti pembuatan filter IPAL dan warga menjadi lebih tahu bagaimana cara pembuatan filter IPAL yang benar. 


\section{KESIMPULAN}

a. Pelaksanaan pengabdian kepada masyarakat di RT 08 RW 03 Kel. Sumur Dewa Kec. Selebar Kota Bengkulu diawali dengan kegiatan survey lapangan oleh tim pengmas Fakultas Ilmu Kesehatan UM Bengkulu.

b. Pelaksanaan kegiatan penyuluhan kesehatan tentang dampak sampah plastic terhadap kesehatan dilaksanakan di Lingkungan RT 08 RW 03 Kel. Sumur Dewa Kec. Selebar Kota Bengkulu dengan jumlah peserta sebanyak 25 warga.

c. Pelaksanaan kegiatan penyuluhan kesehatan tentang pemanfaatan botol plastik bekas sebagai filter IPAL Komunal sekaligus demontrasi pembuatan filter IPAL dilaksanakan setelah 2 minggu dari penyuluhan yang pertama di Lingkungan RT 08 RW 03 Kel. Sumur Dewa Kec. Selebar Kota Bengkulu dengan jumlah peserta sebanyak 23 warga.

d. Partisipasi dari warga sangat baik. Banyak warga yang antusias dengan mengajukan beberapa pertanyaan terkait materi-materi yang telah diberikan dan warga juga dapat menjawab pertanyan-pertanyaan yang ditanyakan tim pengmas terkait materi penyuluhan serta cara pembuatan filter yang lebih efektif.

\section{DAFTAR PUSTAKA}

Daryanto,2004, Masalah Pencemaran, Bandung, Tarsito.

Kementerian Pekerjaan Umum dan Perumahan Rakyat, 2017, Perencanaan IPAL Komunal Berbasis Sanitasi, Jakarta.

Prameswari, RA. and Purnomo, A.Perencanaan Pelayanan Air Limbah Komunal di Desa Krasak Kecamatan Jatibarang Kota Indramayu, 2014. Jurnal Teknik POMITS, vol. 3,no. 2.p.81-84.

Sapel, A., Purwanto, M Y., dan Kurniawan, A. 2011, Desain Instalasi Pengolah Limbah WC Komunal Masyarakat Pinggir Sungai Desa Lingkar Kampus.Jurnal Ilmu Pertanian Indonesia, vol 16,no. 2, p.91-99. 